\title{
Regulation of Sulphur Metabolism in Paracoccus denitrificans
}

\author{
By J. N. BURNELL*† AND F. R. WHATLEY \\ Botany School, University of Oxford, South Parks Road, Oxford OX1 3RA
}

(Received 24 May 1979; revised 18 September 1979)

\begin{abstract}
The metabolic pathway for the reduction and incorporation of sulphate in Paracoccus denitrificans strain NCIB 8944 has been elucidated and the control and regulation of the pathway is reported. Several enzymes of the sulphate metabolic pathway have been assayed in $P$. denitrificans grown on different substrates. In addition, several enzymes have been purified and in vitro inhibitor studies conducted on them. Cysteine plays a primary role in the control of sulphur metabolism in P. denitrificans.
\end{abstract}

\section{INTRODUCTION}

The metabolic pathway for the activation, reduction and incorporation of sulphate into cysteine and methionine in Paracoccus denitrificans strain NCIB 8944 has been elucidated (Burnell, 1975). The pathway is similar to that found in Escherichia coli, Salmonella typhimurium and Bacillus subtilis as described previously (Pasternak et al., 1965; Kredich \& Tomkins, 1966; Jones-Mortimer et al., 1968; Jones-Mortimer, 1968). In summary, the pathway involves uptake of sulphate, its activation and reduction to sulphide via sulphite and the addition of sulphide to serine to form cysteine; subsequently, homocysteine formed via cystathionine is methylated to give methionine. This paper reports some aspects of the regulation of the assimilatory sulphate pathway in $P$. denitrificans.

\section{METHODS}

Chemicals. All chemicals were of analytical reagent grade. Scintillation fluid contained $7 \mathrm{~g}$ butyl-PBD [2-(4'-tert-butylphenyl)-5-(4"'-biphenylyl)-1,3,4-oxadiazole] and $80 \mathrm{~g}$ naphthalene made up to 11 with toluene/2-methoxyethanol $(6: 4, \mathrm{v} / \mathrm{v})$.

Maintenance and growth of organisms. Paracoccus denitrificans NCIB 8944 (Davis et al., 1969) was maintained and grown with succinate as the substrate and nitrate as the added terminal electron acceptor as described by Burnell et al. (1975a).

Assay of sulphate uptake. Cells were harvested by centrifuging 21 cell suspension during the exponential growth phase. They were washed twice in 21 washing medium (culture medium minus sulphur source), resuspended in 11 washing medium and re-incubated for $30 \mathrm{~min}$ at $30^{\circ} \mathrm{C}$ to deplete the cells of intracellular sulphate. Sulphate uptake was measured at $30^{\circ} \mathrm{C}$ in reaction mixtures (total vol. $5 \mathrm{ml}$ ) containing $3.0 \mathrm{ml}$ washed cell suspension, $1.9 \mathrm{ml}$ washing medium and $0.1 \mathrm{ml} \mathrm{Na}_{2}{ }^{35} \mathrm{SO}_{4}\left[10 \mathrm{~mm} ; 1 \mathrm{Ci} \mathrm{mol}^{-1}\left(37 \mathrm{GBq} \mathrm{mol}^{-1}\right)\right]$; the ${ }^{35}$ S $]$ sulphate was added at zero time. (In experiments testing inhibitors of sulphate uptake, ${ }^{35}$ S $]$ sulphate and the inhibitor were added at the same time.) Samples $(0 \cdot 1 \mathrm{ml})$ were withdrawn at $15 \mathrm{~s}$ intervals for $2 \mathrm{~min}$ and added to $2.0 \mathrm{ml} 10 \mathrm{~mm}-\mathrm{Na}_{2} \mathrm{SO}_{4}$ at $2{ }^{\circ} \mathrm{C}$. After $5 \mathrm{~min}$ the cells were collected by filtration on Oxoid membrane filters $(0.45 \mu \mathrm{m}$ pore size; $4.7 \mathrm{~cm}$ diam. $)$ and washed with $10 \mathrm{mM}-\mathrm{Na}_{2} \mathrm{SO}_{4}$. The filters were placed in scintillation vials, dried and, following addition of $5 \mathrm{ml}$ scintillation fluid, the radioactivity was counted.

Chromatography and identification of $\left.{ }^{35} \mathrm{~S}\right]$ sulphate. The validity of the sulphate uptake assay was verified by taking hot water washings of cells following a 2 min sulphate uptake assay, pooling these washings, evaporating them to dryness in a rotary evaporator and dissolving the residue in water; fractions $(0.05 \mathrm{ml})$ were applied to Whatman $3 \mathrm{MM}$ paper and developed for $16 \mathrm{~h}$ by descending chromatography in propan-1-ol/

$\dagger$ Present address: School of Environmental and Life Sciences, Murdoch University, Murdoch, Western Australia 6153, Australia. 


\section{Table 1. Enzyme and uptake activities in extracts of $P$. denitrificans} grown on different sulphur sources

$\begin{array}{cccc}\begin{array}{c}\text { Sole } \\ \text { sulphur source }\end{array} & \begin{array}{c}\text { Sulphur } \\ \text { uptake }\end{array} & \begin{array}{c}\text { ATP } \\ \text { sulphurylase* }\end{array} & \begin{array}{c}\text { APS } \\ \text { kinase }\end{array} \\ \text { Sulphate } & 0.038 & 0.27 & 7.62 \\ \text { Sulphite } & 0.014 & 0.13 & 3.83 \\ \text { Sulphide } & 0.009 & 0.06 & 0.49 \\ \text { Cyst(e)ine } & 0.003 & 0.02 & 0.15\end{array}$

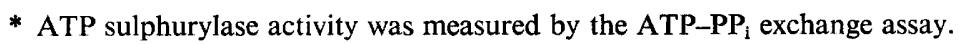

$\mathrm{NH}_{3}$ (sp.gr. $\left.0 \cdot 88\right) /$ water $(6: 3: 1$, by vol.). Dried chromatogram strips were cut into $1 \mathrm{~cm}$ sections and their radioactivity was determined using a scintillation counter. $\left[{ }^{35} \mathrm{~S}\right]$ Sulphate was identified by comparing the $R_{F}$ value of the radioactive fraction of the hot water washings with the $R_{F}$ value of authentic $\left[{ }^{35} \mathrm{~S}\right] \mathrm{sulphate}$.

Enzyme assays. ATP sulphurylase [ATP:sulphate adenylyltransferase; EC 2.7.7.4] activity was measured

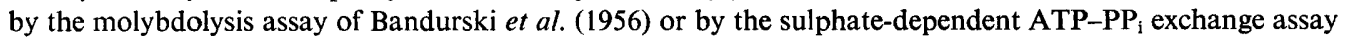
of Shaw \& Anderson (1971, 1972). Inorganic pyrophosphatase [pyrophosphate phosphohydrolase; EC 3.6.1.1] activity was measured by the method of Shaw \& Anderson (1972). APS kinase [ATP:adenylylsulphate $3^{\prime}$-phosphotransferase; EC 2.7.1.25] activity was measured by the method of Burnell \& Whatley (1975).

Protein determination. Protein was determined by the method of Lowry using bovine serum albumin as standard.

Purification of ATP sulphurylase. All operations were conducted at $4{ }^{\circ} \mathrm{C}$ and the buffer used throughout contained $20 \mathrm{~mm}$-Tris/ $\mathrm{HCl}, \mathrm{pH} 8.0$ and $5 \mathrm{~mm}-\mathrm{MgCl}_{2}$ unless specified otherwise. Crude extracts were prepared as described by Burnell et al. $(1975 \mathrm{a})$. The protein precipitating between 30 and $80 \%$ saturation with solid ammonium sulphate was dissolved in buffer and passed through a column $(30 \times 1.5 \mathrm{~cm})$ of Dowex AG 11A8, 50 to 100 mesh, ion retardation resin. Fractions $(5 \mathrm{ml})$ were collected and those containing the bulk of the protein were pooled and applied to a column $(75 \times 3.5 \mathrm{~cm})$ of Sephadex G-200. From the Sephadex column, those fractions containing ATP sulphurylase but no inorganic pyrophosphatase activity were pooled and applied to a column $(7.5 \times 3.5 \mathrm{~cm})$ of DEAE- 52 cellulose. The column was washed with $50 \mathrm{ml}$ $0 \cdot 2 \mathrm{M}-\mathrm{KCl}$ dissolved in buffer and ATP sulphurylase was eluted with a $500 \mathrm{ml} 0.2$ to $0.5 \mathrm{M}-\mathrm{KCl}$ gradient. The fractions with the highest specific activity were pooled and dialysed against buffer.

Purification of inorganic pyrophosphatase. The crude extract was prepared and ammonium sulphate fractionation was carried out as described for the purification of ATP sulphurylase. Following dialysis the enzyme solution was applied to a column $(75 \times 3.5 \mathrm{~cm})$ of Sephadex G-200 and those fractions containing inorganic pyrophosphatase but no ATP sulphurylase activity were pooled. The pooled fractions were loaded on to a column $(8.0 \times 3.5 \mathrm{~cm})$ of DEAE-52 cellulose and the pyrophosphatase was eluted with a $250 \mathrm{ml}$ 0.15 to $0.4 \mathrm{M}-\mathrm{KCl}$ gradient. Fractions containing the highest specific activity of inorganic pyrophosphatase were pooled and dialysed against buffer.

\section{RESULTS}

In studying a sulphate transport or uptake system in intact cells it is important to determine sulphate uptake separately from sulphate incorporation by ascertaining the extent to which sulphate is free to leave the cell after it has been taken up. In experiments with Salmonella typhimurium, Dreyfuss (1964) used mutants which lacked the sulphate-activating enzymes, thereby avoiding confusing sulphate uptake and sulphate incorporation. Of the $\left.{ }^{35} \mathrm{~S}\right]$ sulphate taken up by $P$. denitrificans in 2 min $99.7 \%$ of the radioactivity was recovered by washing the cells with water at $100{ }^{\circ} \mathrm{C}$; all the radioactivity recovered was in the form of sulphate as demonstrated by paper chromatography. Therefore, the method of measuring the rate of sulphate uptake is essentially the same as that used by Yamamoto \& Segel (1966) in their studies with Penicillium, being a determination of the amount of free $\left[{ }^{35}\right.$ S]sulphate within the cells following a brief incubation period. However, unlike the method of Yamamoto \& Segel (1966), the sulphate extracted by boiling water was not measured; instead, the time of the assay was restricted to a period over which all the sulphate taken up by the cells could 
Table 2. Effect of intermediates of the sulphur metabolic pathway on ATP sulphurylase and sulphate uptake in P. denitrificans

Sulphur metabolic pathway intermediates were added to sulphate uptake assays at $0.05 \mathrm{~mm}$ and to ATP sulphurylase assays at $5.0 \mathrm{~mm}$.

ND, Not determined.

\begin{tabular}{|c|c|c|}
\hline \multirow[b]{2}{*}{ Intermediate added } & \multicolumn{2}{|c|}{ Inhibition $(\%)$} \\
\hline & $\begin{array}{l}\text { Sulphate } \\
\text { uptake }\end{array}$ & $\begin{array}{c}\text { ATP } \\
\text { sulphurylase* }\end{array}$ \\
\hline Sulphate & 0 & 0 \\
\hline APS & ND & 77 \\
\hline Pyrophosphate & ND & 16 \\
\hline Sulphite & 89 & 0 \\
\hline Thiosulphate & 46 & ND \\
\hline Sulphide & 37 & 76 \\
\hline Cysteine & 13 & 0 \\
\hline Cystathionine & ND & 0 \\
\hline Homocysteine & ND & 0 \\
\hline Methionine & 9 & 0 \\
\hline$O$-Acetylserine & ND & 0 \\
\hline
\end{tabular}

* ATP sulphurylase was assayed by the ATP-PP $P_{1}$ exchange assay; the specific activity of the $\mathrm{PP}_{1}$ was maintained at a constant level.

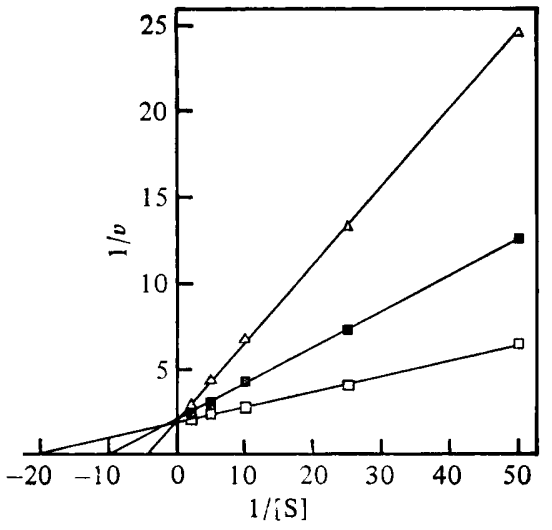

Fig. 1

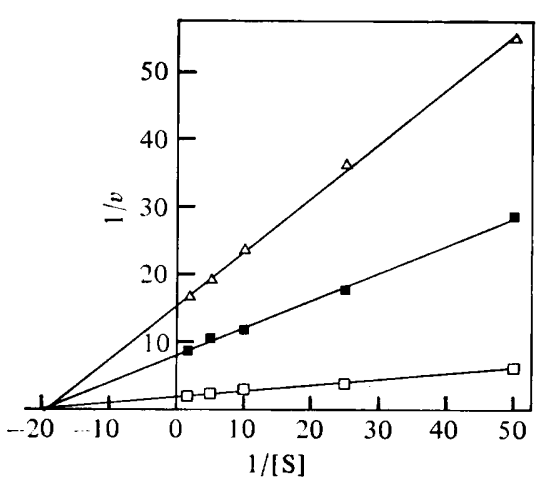

Fig. 2

Fig. 1. Double reciprocal plots of sulphate concentration (mM) versus the rate of sulphate uptake $\left.\left[\mu \mathrm{mol} \mathrm{min}^{-1} \text { (mg protein) }\right)^{-1}\right]$ in the presence or absence of thiosulphate. Reaction mixtures were as described in Methods except that sulphate and thiosulphate were added at the concentrations specified: $\square$, no thiosulphate; $\square, 0.02$ mM-thiosulphate; $\triangle, 0.05$ mM-thiosulphate.

Fig. 2. Double reciprocal plots of sulphate concentration (mM) versus the rate of sulphate uptake $\left[\mu \mathrm{mol} \mathrm{min}^{-1}(\mathrm{mg} \text { protein })^{-1}\right]$ in the presence or absence of sulphite. Reaction mixtures were as described in Methods except that sulphate and sulphite were added at the concentrations specified: $\square$, no sulphite; $\square, 0.02 \mathrm{~mm}$-sulphite; $\triangle, 0.05 \mathrm{~mm}$-sulphite.

have been quantitatively extracted as free inorganic sulphate and the radioactivity in the cells was counted. The validity of this method therefore rests on the demonstration that practically all the sulphate taken up in 2 min can be extracted as sulphate by boiling water. The sulphate uptake assay was linear for at least $5 \mathrm{~min}$.

The sulphate uptake mechanism, ATP sulphurylase and APS kinase were repressed by growth on sulphite, sulphide and cysteine (Table 1). Sulphate uptake was strongly inhibited by sulphite, thiosulphate and sulphide and partially inhibited by cysteine (Table 2); kinetic studies showed that the inhibition by thiosulphate was competitive (Fig. 1)and theinhibition 


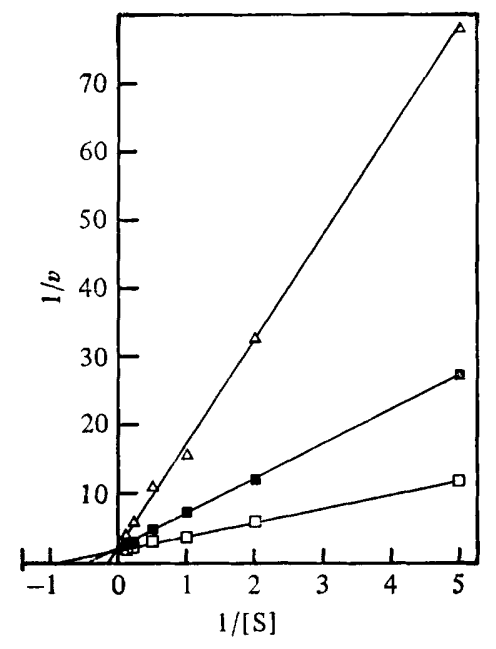

Fig. 3. Double reciprocal plots of sulphate concentration (mM) versus the rate of sulphatedependent ATP-PP exchange $\left[\mathrm{nmol} \mathrm{min}^{-1}(\mathrm{mg} \text { protein })^{-1}\right]$ in the presence or absence of sulphide. Reaction mixtures were as described in Methods except that sulphate and sulphide were added at the concentrations specified: $\square$, no sulphide; $\square, 2.0 \mathrm{~mm}$-sulphide; $\triangle, 5.0 \mathrm{~mm}$-sulphide.

by sulphite (Fig. 2) and sulphide (results not shown) was non-competitive. ATP sulphurylase was inhibited by sulphide and the end-products of the reaction, APS and PP (Table 2); the inhibition by sulphide was competitive with respect to sulphate (Fig. 3). No inhibition studies were conducted with APS kinase. The regulation of serine transacetylase, $O$-acetylserine sulphydrylase and $\beta$-cystathionase in $P$. denitrificans has been reported previously (Burnell \& Whatley, 1977a), as has the regulation of cysteinyl- and methionyl-tRNA synthetase (Burnell \& Whatley, 1977b).

In all enzyme and uptake systems investigated the inhibition by sulphite and sulphide was reversible; removal of sulphide from reaction mixtures by dialysis indicated no inactivation by sulphide. Furthermore, addition of $\mathrm{Mg}^{2+}$ to reaction mixtures did not affect sulphide inhibition.

\section{DISCUSSION}

Repression of one of the first enzymes in a metabolic pathway by the end-product of that pathway is a common mechanism of control in bacteria (Pardee, 1959). Therefore, it is not surprising that the sulphate uptake mechanism was repressed by growth on cysteine; cells of $P$. denitrificans grown on cysteine as the sole sulphur source lack the sulphate carrier (Burnell et al., 1975b). The non-competitive inhibition of sulphate uptake by sulphite and sulphide suggests that they may function as physiological feedback inhibitors of sulphate uptake. Competitive inhibition of sulphate uptake by thiosulphate and the structural similarity between sulphate and thiosulphate suggests that thiosulphate and sulphate compete for the binding sites on the sulphate-carrier protein. The partial inhibition of the sulphate uptake system in $P$. denitrificans differs from the complete end-product inhibition of the sulphate uptake system in $E$. coli (Ellis, 1964) but resembles the pattern of inhibition of the sulphate transport mechanism in S. typhimurium (Dreyfuss, 1964). Repression of sulphate activation by growth on cysteine has been reported previously in E. coli and B. subtilis (Pasternak, 1962) and S. typhimurium (Kline \& Schoenhard, 1970; Kredich, 1971). In contrast to E. coli (Jones-Mortimer et al., 1968) the growth of $P$. denitrificans on cysteine caused a doubling in the specific activity of serine transacetylase and $O$-acetylserine sulphydrylase. These two enzymes appear to be constitutive enzymes in $P$. denitrificans and are controlled by feedback inhibition (Burnell \& Whatley, 1977a). The fact that these enzymes may be constitutive 


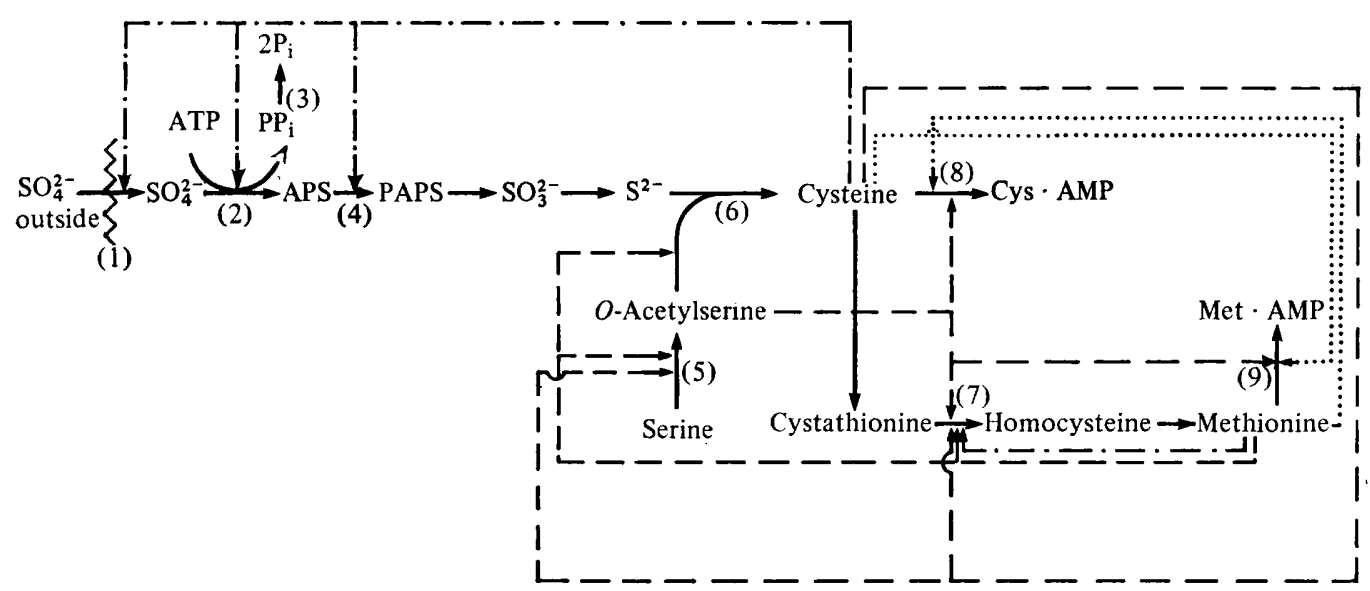

Fig. 4. The pathway and the role of cysteine, methionine and $O$-acetylserine in the control of sulphur metabolism in $\boldsymbol{P}$. denitrificans (APS, adenosine 5'-phosphosulphate; PAPS, 3'-phosphoadenosine 5'-phosphosulphate). Cysteine represses enzymes (1), (2) and (4) and is a feedback inhibitor of enzyme (5). Cysteine also inhibits enzyme (7). $O$-Acetylserine inhibits enzymes (7), (8) and (9). Methionine represses enzyme (7) and inhibits enzymes (5), (6) and (7). Cysteine and methionine stimulate enzymes (9) and (8), respectively. Enzymes: (1) sulphate uptake system; (2) ATP sulphurylase;(3) pyrophosphatase; (4) APS kinase; (5) serine transacetylase; (6) $O$-acetylserine sulphydrylase; (7) $\beta$-cystathionase; (8) cysteinyl-tRNA synthetase; (9) methionyl-tRNA synthetase. $-\cdots \rightarrow$, Repression; $----\rightarrow$, inhibition; $\cdots \rightarrow \rightarrow$, stimulation; $m$ m, cell membrane.

provides a possible means of converting toxic sulphide to a less toxic form should it be produced intra- or extracellularly.

According to the results reported in this and other papers (Burnell et al., 1975a; Burnell \& Whatley, $1977 a, b)$ cysteine plays a central role in the regulation of sulphur metabolism in $P$. denitrificans. Cysteine is involved in, or has an effect upon, almost every enzyme or uptake system examined in this study. Cysteine represses sulphate uptake and sulphate activation, induces higher activity of serine transacetylase and $O$-acetylserine sulphydrylase (Burnell \& Whatley, 1977 $a$ ) and inhibits serine transacetylase and $\beta$-cystathionase (Burnell \& Whatley, $1977 a$ ) in addition to stimulating methionyl-tRNA synthetase (Burnell \& Whatley, $1977 b$ ) (Fig. 4). $O$-Acetylserine and methionine also play important roles in the sulphur metabolic pathway and its regulation (see Fig. 4).

Although cysteine, methionine and $O$-acetylserine are not the only compounds involved in the regulation of sulphur metabolism in $P$. denitrificans they do appear to be the most important. Homocysteine and sulphide also play significant roles in the regulation of sulphur metabolism in $P$. denitrificans (see Burnell \& Whatley, $1977 a, b$; Burnell et al., 1975b). No conclusions can be drawn on the role of sulphite and sulphide independently of cysteine in the repression of the sulphate uptake or sulphate activation systems in $P$. denitrificans as both sulphite and sulphide will ultimately be incorporated into cysteine and the extent of enzyme repression by sulphite and sulphide may only reflect the relative rates of incorporation of these two anions into cysteine.

A scheme summarizing the pathway of sulphur metabolism and the roles of cysteine, $O$-acetylserine and methionine in the regulation of the enzymes and the uptake system of sulphur metabolism studied in $P$. denitrificans is shown in Fig. 4. No conclusions relating to the overall regulation of methionine biosynthesis can be drawn from this scheme as cystathionine $\gamma$-synthase and homoserine transsuccinylase were not included in this investigation.

J. N. Burnell was the holder of an 1851 Royal Commission Scholarship. 


\section{REFERENCES}

Bandurski, R. S., Wilson, L. G. \& Squires, C. L. (1956). The mechanism of 'active sulfate' formation. Journal of the American Chemical Society 78, 6408-6409.

BurNell, J. N. (1975). Sulphur metabolism in Paracoccus denitrificans. D.Phil. thesis, University of Oxford.

BurNell, J. N. \& Whatley, F. R. (1975). A new, rapid and sensitive assay for adenosine- $5^{\prime}$ phosphosulphate (APS) kinase. Analytical Biochemistry 68, 281-288.

Burnell, J. N. \& Whatley, F. R. (1977a). Sulphur metabolism in Paracoccus denitrificans: purification, properties and regulation of serine transacetylase, $O$-acetylserine sulphydrylase and $\beta$ cystathionase. Biochimica et biophysica acta 481, 246-265.

BurNell, J. N. \& Whatley, F. R. (1977b). Sulphur metabolism in Paracoccus denitrificans: purification, properties and regulation of cysteinyl- and methionyl-tRNA synthetase. Biochimica et biophysica acta 481, 266-278.

Burnell, J. N., JohN, P. \& Whatley, F. R. $(1975 a)$. The reversibility of active transport in membrane vesicles of Paracoccus denitrificans. Biochemical Journal 150, 527-536.

Burnell, J. N., John, P. \& Whatley, F. R. (1975b). Phosphate transport in membrane vesicles of Paracoccus denitrificans. FEBS Letters 58, 215-218.

Davis, D. H., Doudoroff, M., Stanier, R. Y. \& MANDEL, M. (1969). Proposal to reject the genus Hydrogenomonas: taxonomic implications. International Journal of Systematic Bacteriology 19, 375-390.

Dreyfuss, J. (1964). Characterization of a sulfate and thiosulfate-transporting system in Salmonella typhimurium. Lournal of Biological Chemistry 239, 2292-2297.

Ellis, R. J. (1964). The site of end product inhibition of sulphate reduction in Escherichia coli. Biochemical Journal 93, 19P.

Jones-Mortimer, M. C. (1968). Positive control of sulphate reduction in Escherichia coli. The nature of the pleiotropic cysteineless mutants of $E$. coli K12. Biochemical Journal 110, 597-602.

Jones-Mortimer, M. C., Wheldrake, J. F. \& Pasternak, C. A. (1968). The control of sulphate reduction in Escherichia coli by $O$-acetylserine. Biochemical Journal 107, 51-53.

Kline, B. C. \& Schoenhard, D. E. (1970). Biochemical characterization of sulphur assimilation by Salmonella pullorum. Journal of Bacteriology 102, 142-148.

KREDICH, N. M. (1971). Regulation of L-cysteine biosynthesis in Salmonella typhimurium: effects of growth on varying sulfur sources and $O$-acetylserine on gene expression. Journal of Biological Chemistry 246, 3474-3484.

Kredich, N. M. \& Tomkins, G. M. (1966). The enzymic synthesis of L-cysteine in Escherichia coli and Salmonella typhimurium. Journal of Biological Chemistry 241, 4955-4965.

PARdeE, A. B. (1959). In Regulation of Cell Metabolism, CIBA Foundation Symposium, p. 295. Edited by G. E. W. Wolstenholme \& C. M. O'Connor. London: J. \& A. Churchill.

PAsternak, C. A. (1962). Control of sulphate activation in Escherichia coli and Bacillus subtilis. Biochemical Journal 85, 44-49.

Pasternak, C. A., Ellis, R. J., Jones-Mortimer, M. C. \& Crichton, C. E. (1965). The control of sulphate reduction in bacteria. Biochemical Journal 96, 270-275.

Shaw, W. H. \& ANderson, J. W. (1971). Assay of adenosine 5 -triphosphate sulfurylase by pyrophosphate exchange. Plant Physiology 47, 114-118.

Shaw, W. H. \& Anderson, J. W. (1972). Purification, properties and substrate specificities of ATP sulphurylase from spinach leaf tissue. Biochemical Journal 127, 237-247.

Yamamoto, L. H. \& Segel, I. H. (1966). The inorganic sulphate transport system of Penicillium chrysogenum. Archives of Biochemistry and Biophysics 114, 523-538. 